\title{
DISCOVERY-TECHNIQUE-BASED TEACHING IN SECONDARY VOCATIONAL EDUCATION
}

\author{
[BADATELSKE VYUCOVANIE V STREDOSKOLSKOM \\ ODBORNOM VZDELAVANI]
}

\author{
Timea Seben Zatkova - Zuzana Bobak
}

doi: 10.18355/PG.2022.11.1.5

\begin{abstract}
One of many alternatives available for teaching is inquiry-based teaching. In this type of teaching, the student is in the role of a researcher and the teacher in the role of the creator of learning activities and in certain phases also a guide for students. The aim of this study was to map the opinions and experiences of teachers with inquiry-based teaching and its implementation into secondary vocational education teaching. The research methodology was based on a questionnaire survey among secondary school teachers with the largest representation from the Nitra region. The results show that although awareness of inquiry-based teaching reaches 55\% among the teachers, the practical implementation is low.
\end{abstract}

\section{Key words}

Inquiry-based teaching, secondary schools, vocational teaching subjects, teachers' opinions

\begin{abstract}
Anotácia
Jednou z mnohých dostupných alternatív výučby je bádatel'ské vyučovanie. Pri tomto type výučby je žiak v úlohe výskumníka a učitel' v úlohe tvorcu učebných aktivít a v určitých fázach je aj sprievodcom žiakov. Cielom tejto štúdie bolo zistit' názory a skúsenosti učitel'ov s bádatel'ským vyučovaním a jeho implementáciou do vyučovania v stredoškolskom odbornom vzdelávaní. Metodika výskumu vychádzala $\mathrm{z}$ dotazníkového prieskumu medzi učitel'mi stredných škôl s najväčším zastúpením z Nitrianskeho kraja. Výsledky ukazujú, že hoci informovanost' učitel'ov o bádatel'skom vyučovaní dosahuje $55 \%$, jeho praktická implementácia v školách je nízka.
\end{abstract}

\section{Kl’účové slová}

Bádatel'ské vyučovanie, stredné školy, odborné vyučovacie predmety, názory učitel'ov

\section{Úvod}

Vyučovanie badaním, objavovaním je jedným z účinných prístupov problémového vyučovania, $\mathrm{v}$ rámci ktorého si žiaci osvojujú postupy a spôsoby myslenia, ktoré veda používa. Takýto vyučovací proces patrí $\mathrm{k}$ aktivizujúcim a v slovenskom prostredí $\mathrm{k}$ relatívne novším spôsobom vyučovania. 
V anglicky písaných prameňoch sa pojem bádatel'ské vyučovanie začal viac objavovat' od 60. rokov 20. storočia (Dostál, 2015).

Tento reformný proces volajúci po zmene smerom ku konštruktivistickému prístupu vo vzdelávaní sa začal v USA už v druhej polovici 20. storočia, odkedy sa objavujú pojmy Inquiry-based learning of Science/ Inquiry-Based Science Learning (IBSL), Inquiry-based Science Teaching (IBST) alebo Inquiry-based science education (IBSE). V anglicko - slovenskom i v českom pedagogickom slovníku je pojem inquiry teaching alebo inquiry method preložene ako vyučovanie bádaním, objavovaním, bádatel'ská metóda (Sotakova, 2018). Ked’že slovo „Inquiry“ (skúmanie, pátranie, vyšetrovanie, bádanie a pod.) nemá v slovenskom jazyku presný ekvivalent zodpovedajúci jeho obsahu, preto sa možno stretnút' s rozličnými prekladmi ako napríklad "učenie založené na aktívnom žiackom badaní alebo aktívne prírodovedné bádanie (Ješkova, Kireš, Onderova, 2012). Niektorí autori hovoria aj o objavnom vyučovaní, či termín „výskumne ladená koncepcia vzdelávania. V Čechách od roku 2010 zase Badatelsky orientované přirodovědné vzdělávaní (vyučování) (Kireš et al., 2016).

Vd’aka medzinárodným projektom na európskej úrovni S-TEAM (Science Teacher Education Advanced Methods, 2010-2013), ESTABLISH (European Science and Technology in Action: Building Links with Industry, Schools and Home, 2010-13), PRI-SCI-NET (Networking Primary Science Educators as a means to provide training and Professional development in Inquiry Based Teaching, 2011-14) a PROFILES (Professional Reflection-

Oriented Focuson Inquiry-based Learning and Education though Science, 2010-13) financovaných z EÚ, sa šírilo bádatel'sky orientované vyučovanie v prírodovedných predmetoch a rovnako aj vzdelávanie učitel'ov. A práve preto sa dominantne spája s prírodovednými predmetmi, až následne s príchodom nových projektov sa začínalo spájat's matematikou a technickými odbormi ako napr. projekty FIBONACCI (2010- 2013), ASSIST-ME (Assess Inquiry in Science, Technology and Mathematics Education, 2013-16) a MaSciL aktivitami v prírodovednom, technickom a matematickom vzdelávaní (podl'a Kireš et al., 2016). Na Slovensku sa realizovali medzinárodné projekty Fibonacci, ESTABLISH, SAILS - Strategies for Assessement Inquiry Learning in Science, PRIMAS, CHREACT, POLLEN (Leškova, Skupekova a Kimakova, 2019; Kireš et al., 2016).

Bádatel'sky orientované vyučovanie je dôležitým vyučovacím nástrojom prírodovedných predmetov. Zahŕňa riešenie otázok a problémov žiakmi na základe údajov získaných vlastným skúmaním (Crawford, 2000). Tento spôsob výučby má podporit' vedeckú gramotnost', môže zlepšit' chápanie vedy, ako aj účast' a angažovanost' žiakov vo vede a prírodovedných predmetoch. BOV navyše poskytuje priestor na postupné získavanie vedomostí o podstate bádania a vedeckého poznania (Spodniakova Pfefferova et al., 2015).

Ako na základe vyššie uvedeného možno dedukovat', častejšie sa možno stretnút' s uplatňovaním tohto vyučovania v prírodovednom vzdelávaní, z čoho vyplýva, že teda aj vo vyučovaní odborných predmetov pol'nohospodárskeho, potravinárskeho, či technického zamerania sú všeobecne dostupné obrovské možnosti uplatnenia. Aj ked' na druhej strane 
bádanie a vedecké poznanie je tiež prítomné aj v predmetoch humanitného a spoločensko-vedného zamerania, zastávame názor, že ich uplatňovanie by nemalo byt' obmedzované podl'a odborného zamerania vyučovaných predmetov. Bádatel'sky orientované vyučovanie predstavuje prístup vo vyučovaní, stratégiu riadenia učebných činností žiaka, ktorý sa môže uplatnit' v prírodných aj humanitných vedách.

BOV je to teda cielavedomý proces formulovania problémov, kritického experimentovania, posudzovania alternatív, plánovaného skúmania a overovania, vyvodzovania záverov, vyhl'adávania informácií, vytvárania modelov študovaných dejov, diskusie a formovania koherentných argumentov. Vychádza z konštruktivistických prístupov k učeniu, rešpektuje jedinečnost' každej l'udskej bytosti a nadobudnutie schopnosti a spôsobilosti ako sa učit' považuje za podstatne dôležitejšie ako získavanie hotových informácií. Priame, nesprostredkované skúmanie skutočností, ktoré nás obklopujú, je pre človeka najprirodzenejším spôsobom učenia sa a získavania poznatkov o fungovaní sveta (Karolčik, Laštikova \& Čipkova, 2020).

Vedecké bádanie si vyžaduje nie len poznanie prírodovedného obsahu, ale aj osvojenie si a rozvíjanie príslušných zručností. V odbornej pedagogickej literatúre môžeme nájst' rôzne termíny, ktoré označujú schopnosti a zručnosti žiakov potrebné pre vedecké bádanie, ako napr. spôsobilosti vedeckej práce (science process skills, science inquiry skills, inquiry skills), bádatel'ské zručnosti (scientific inquiry skills, scientific literacy skills ) (Čipkova \& Karolčik, 2018).

\section{Učitel' v bádatel'skom vyučovaní}

Častou prekážkou v uplatňovaní bádatel'ského vyučovania je pripravenost' učitel'ov. Pre učitel'ov je najtažšie sa rozhodnút', ktoré znalosti do BOV začlenit'. Zároveň môže byt' učitel' obmedzovaný možnost'ami školy - jej vybavenost' a priestory. S nedostatočným vybavením tried a škôl (napríklad nedostatok prístrojov, pomôcok, chýbajúce laboratória) motivácia k praktickému aplikovaniu BOV klesá. Mnohí učitelia nemajú tiež dostatočné skúsenosti a riadia sa zjednodušeným vnímaním koncepcie získavania vedeckých poznatkov. Nedostatok vedomostí a skúseností je prekážkou vo výučbe predmetov (Blanchard, Southerland \& Grangerova, 2008). Tieto nedostatky obmedzujú schopnost' učitel'ov vediet' si naplánovat' a zrealizovat' hodiny, ktoré pomáhajú žiakom rozvíjat' ich predstavu o vede netradičným spôsobom (Clapps \& Crawford, 2012).

Aby mohli byt' bádatel'ské zručnosti žiakov primerane rozvíjané, učitel' nemôže podávat' učivo výkladom $\mathrm{v}$ hotovej podobe, ale vyučovací proces plánuje a organizuje tak, aby žiaci sami riešili problémové situácie. Za problémové situácie a úlohy sa $\mathrm{v}$ tomto kontexte považujú otázky, spor, respektíve niečo, čo žiakom nie je jasné. Žiak v týchto situáciách či úlohách $\mathrm{s}$ pomocou učitel'a hl'adá cestu $\mathrm{k}$ riešeniu problému samostatne alebo sa o to aspoň snaží. Pokus alebo pozorovanie sú pri tomto procese nevyhnutné, možno tu využit' i stimuláciu alebo hl'adanie informácií z rôznych zdrojov. Žiak v priebehu BOV neustále reflektuje svoju prácu, dôležitý je spôsob, akým žiak v priebehu bádania premýšla. Mal by tvorit' nápady, testovat' svoje vlastné hypotézy a nebát' sa urobit' chybu. 


\section{Ciel', metódy a metodický postup}

Hlavným ciel’om štúdie je zistit' názory a skúsenosti spojené s uplatňovaním bádatel'sky orientovaného vyučovania (BOV) medzi stredoškolskými učitel’mi a aká je jeho praktická implementácia v edukačnej praxi.

Čiastkové ciele:

1. Zistit' informovanost'/povedomie učitel'ov stredných škôl o bádatel'sky orientovanej výučbe.

2. Zistit' na základe postojov a názorov učitel’ov stredných škôl kladné a problémové stránky bádatel'sky orientovaného vyučovania.

3. Na základe prieskumu vypracovat' profil učitel’a uplatňujúceho BOV.

Skúmanie využívania bádatel'sky orientovaného vyučovania stredoškolskými učitel'mi bolo realizované cez dotazníkový server SURVIO. Dotazník vlastnej konštrukcie s kombinovanými druhmi položiek bol administrovaný stredoškolským učitel'om. Prevažná čast' učitel'ov zapojených do prieskumu bola zo Strednej priemyselnej školy strojníckej a elektrotechnickej v Leviciach, zo Strednej odbornej školy služieb v Leviciach a zo Strednej odbornej školy veterinárnej v Nitre, ale $\mathrm{v}$ menšom počte boli zastúpení aj učitelia $\mathrm{z}$ iných stredných škôl. Prieskumnú vzorku tvorili učitelia stredných škôl, ktorí vyučujú prírodovedné a d’alšie odborné predmety alebo prax. Vzorku tvorilo spolu 40 učitel'ov, z čoho $82 \%$ ženského pohlavia.

\section{Výsledky}

Dotazníkom bola zistená nasledovná štruktúra respondentov:

Tab. 1 Vzdelanie respondentov

\begin{tabular}{|l|l|l|}
\hline Druh vzdelania & $\mathbf{N}$ & $\mathbf{\%}$ \\
\hline $\begin{array}{l}\text { absolventi učitel'ského študijného } \\
\text { programu }\end{array}$ & 21 & $52,5 \%$ \\
\hline $\begin{array}{l}\text { absolventi inžinierskeho štúdia } \\
\text { a doplnená pedagogická } \\
\text { spôsobilost }\end{array}$ & 19 & $47,5 \%$ \\
\hline spolu & 40 & $100 \%$ \\
\hline
\end{tabular}

Tab. 2 Dížka praxe

\begin{tabular}{|l|l|l|}
\hline Dlžka praxe & N & \% \\
\hline nad 16 rokov & 24 & $60 \%$ \\
\hline $11-15$ rokov & 5 & $12,5 \%$ \\
\hline $6-10$ rokov & 4 & $10 \%$ \\
\hline do 5 rokov & 6 & $15 \%$ \\
\hline $\begin{array}{l}\text { bez predchádzajúcej praxe } \\
\text { zač́najúci) }\end{array}$ & 1 & $2,5 \%$ \\
\hline spolu & 40 & $100 \%$ \\
\hline
\end{tabular}

Predmety vyučované respondentmi boli nasledovné: 
Prírodovedné predmety spolu 45\% (18 učitel'ov): biológia - chémia (6 učitel'ov); iba biológia (1 učitel'); biológia $\mathrm{v}$ kombinácii s inými predmetmi (anglicky jazyk, matematika, tovaroznalectvo a cvičenia z tovaroznalectva, aplikované tovaroznalectvo) (5 učitel'ov); chémia v kombinácii s predmetmi (asanácia a hygiena potravín, technológia potravín, informatika) (3 učitelia); fyzika v kombinácii s predmetmi (informatika, matematika) ( 3 učitelia).

Potravinárske a pol'nohospodárske predmety $17,5 \%$ ( 7 učitel'ov): kombinácie predmetov: mikrobiológia a parazitológia, anatómia a fyziológia zvierat, vyžíva a kŕmenie hospodárskych zvierat, chov zvierat, chov hospodárskych zvierat, chov psov, odborné predmety živočíšnej výroby, hygiena potravín, technológia prípravy pokrmov, odborná prax, záhradníctvo, pestovanie rastlín, základy rastlinnej výroby.

Technické a ekonomické predmety 17,5\% (7 učitel’ov): kombinácie predmetov: informatika a ekonomika; motorové vozidlá, stroje a zariadenia; odborné predmety strojárske, prax; odborné predmety zamerané na strojníctvo a informatiku (strojníctvo, mechatronika, programovanie CNG systémov, aplikovaná informatika, grafické systémy, CAD systémy); odborná prax, kontrola a meranie, AutoCAD.

Odborný výcvik - čašník, servírka 12,5\% (5 učitel’ov).

Humanitné a spoločenskovedné predmety 7,5\% (3 učitelia) : pedagogika, v kombináciách dejepis a telesná výchova, slovenský jazyk a literatúra, občianska výchova, etická výchova.

Učitelia mali v prieskume uviest', či vedia vysvetlit' podstatu bádatel'sky orientovaného vyučovania (BOV). Odpovede ilustrujeme v obrázku 1.

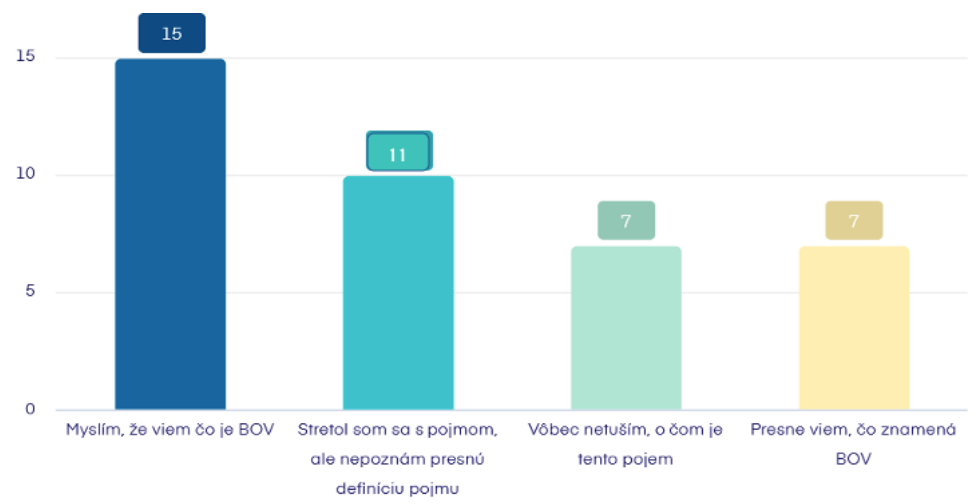

\section{Obr. 1 Poznanie bádatel'sky orientovaného vyučovania učitel'mi}

Následne mali učitelia uviest' $\mathrm{v}$ otvorených odpovediach charakteristiku BOV. Pre ilustráciu uvádzame konkrétne odpovede, ktoré považujeme za tie, ktoré vystihli podstatu BOV:

- „Vyučovací proces zameraný napr. na prezentáciu samostatných prác žiakov, ktorými prídu sami na niektoré dôležité fakty. Odbúra sa memorovanie učiva, myslím si, že BOV je súčastou problémového vyučovania “. 
- „Zameriava sa na skúmanie nových poznatkov prirodzenými spôsobmi, žiak je v postavení výskumníka, zvedavého pozorovatel'a, zameriava sa aj na kreatívne vysvetlovanie s ciel'om inovovat' metódy".

- „Vyučovanie, pri ktorom žiak nie je pasívnym prijímatel'om informácií, ale vystupuje ako "vedec, výskumník” ktorý si musí sám nájst' problém a riešit' ho, pričom prezentuje svoje výsledky. Poznáme niekol'ko stupňov BOV podl'a skúseností žiakov".

- „Vyslovenie hypotézy, výskumom (badaním) potvrdeniel vyvrátenie hypotézy/ zadanie problému, vyslovenie hypotézy, výskum, bádanie, potvrdenie alebo vyvrátenie hypotézy".

Ďalšie boli odpovede, ktoré boli čiastočné a pomenovali BOV ako: - „,výskumné vyučovanie“; „prieskum, objavovat'/ skúmanie, objavovanie /skúmat"; ,učenie objavovaním “; ,učenie na základe získavania informácii"; „,naviest’ žiakov aby prišli na odpovede sami vlastným výskumom danej problematiky“; „s podporou učitel'a dospiet' $k$ novým poznatkom“; „žiak pomocou učitel’a objavuje“; „žiak pomocou vlastného skúmania nájde odpovede“; ,žiak nadobúda vedomosti badaním, skúmaním, pokusmi, experimentami“; ,získavanie vedomostí a zručností bádaním “; ,žiaci svojim úsilím - hladaním, skúšaním, pokusmi nadobúdajú vedomosti“; ,zadat’ žiakom projekt, ktorým sa dopracujú $k$ nejakému vopred neznámemu výsledku“; „žiaci sami hl’adajú riešenia problémov“; „žiak má získat” informácie vlastnou prácou“; „,nastolenie problému, ktorý riešia žiaci“; „riešenie problémových úloh, rozvoj kritického myslenia žiakov“; „vyučovanie zamerané na riešenie problému“; „s využitím experimentov, problémových úloh... “; „,bádatel'sky orientované vyučovanie má pomáhat' rozvijat' žiakom ich praktické zručnosti, aplikovat' teoretické poznatky v praxi a prepájat' učivo s reálnym životom“; ,, aplikovanie teoretických poznatkov v praxi a prepojenie učiva s reálnym životom“; „aktivita, ktorá pomáha rozvijat' žiakom ich praktické schopnosti “; ,pomocou experimentov odvodit” zákonitosti“; ,jedna z metód - heuristická"“.

Pri následnej otvorenej otázke uviedli učitelia rôzne spôsoby, akými sa dozvedeli o bádatel'sky orientovanom vyučovaní. Medzi najčastejšie spôsoby uvádzali dotazník $\mathrm{k}$ záverečnej práci a internet, obe dosiahli 10 odpovedí (25\%). Respondenti uvádzali odpovede typu: „od vás“; „z vášho dotazníka“; , nepočula som o tomto pojme, ale intuitívne som ho využívala“.

Pod kategóriu zdroj informácií internet sú zahrnuté sociálne siete. Ďalšie odpovede boli zamerané na informácie, ktoré získali učitelia počas školenia (školenie, IT akadémia, webinár v rámci dištančného vzdelávania, náhodne pri účasti na inom type vzdelávania pri dištančnom vzdelávaní) - 9 učitel'ov (22,5\%). Počas štúdia na vysokej škole (na prednáškach) získalo informácie o BOV 5 učitel'ov (12,5\%). V počte 3 učitelia (7,5\%) využili pedagogickú odbornú literatúru (sebavzdelávanie) a osobný kontakt (rozhovor s kolegami, študenti na odbornej pedagogickej praxi na strednej škole).

V d’alšej položke sme sa orientovali na zistenie účasti a motivácie $\mathrm{k}$ d'alšiemu vzdelávaniu učitel'ov voblasti BOV. Na základe odpovedí bohužial' musíme konštatovat', že polovica respondentov o takéto 
vzdelávanie záujem ani neprejavuje, pričom iba vel'mi malá čast' vzdelávanie absolvovala aj na základe vlastného záujmu o problematiku. Odpovede uvádzame spracované v nasledujúcom obrázku.

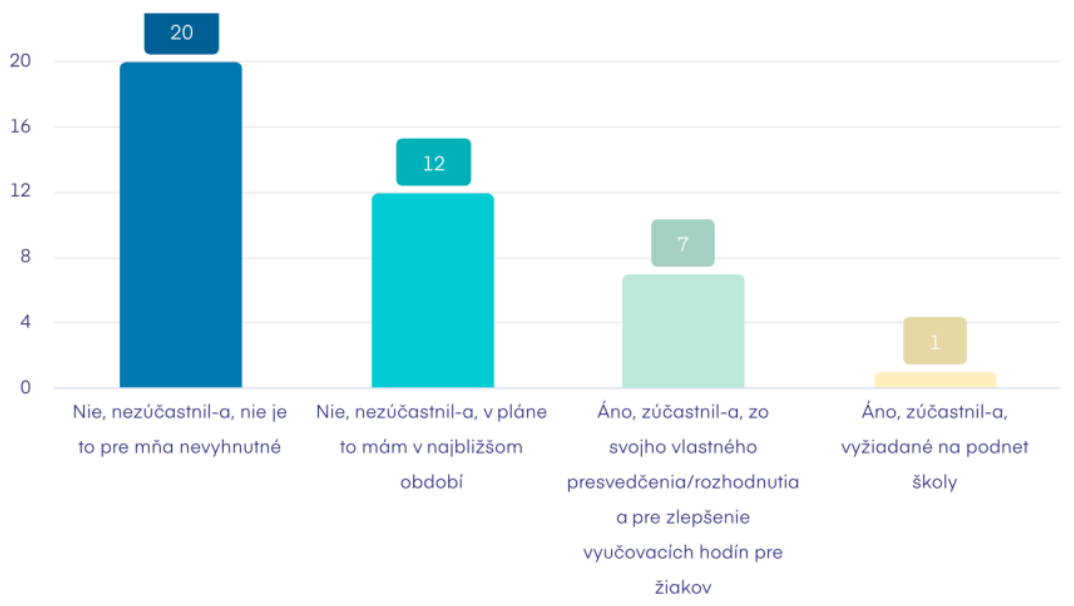

\section{Obr. 2 Účast’ na vzdelávaní k BOV}

Indikovaný relatívne vysoký nezáujem o štúdium problematiky koreluje aj s výsledkami d'alšej položky (obr. 3), v ktorej nadpolovičná čast' respondentov uviedla, že BOV vo svojej edukačnej praxi nevyužívajú.

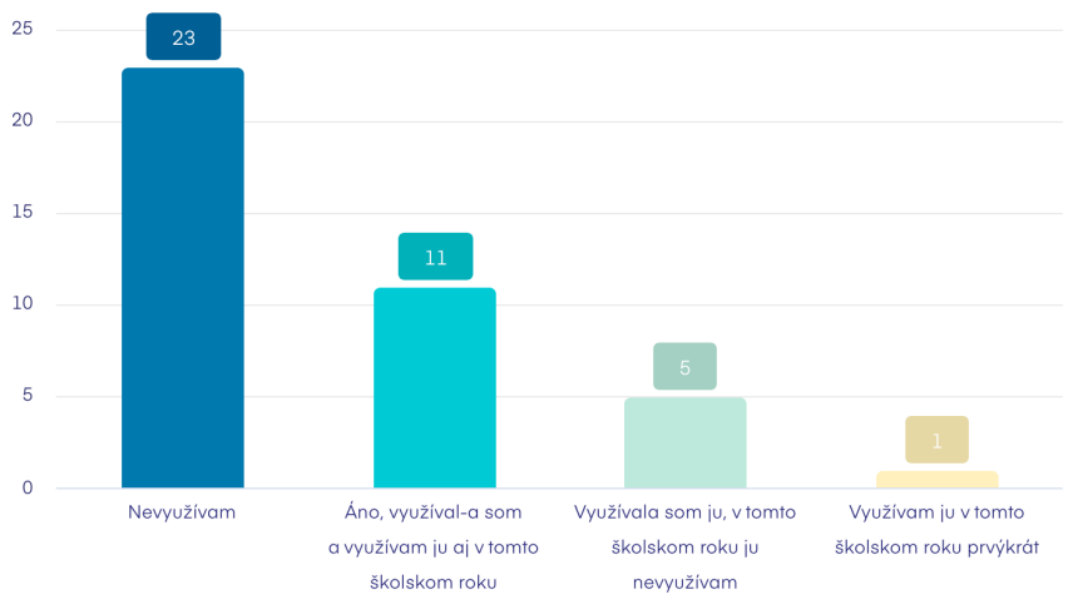

Obr. 3 Uplatňovanie bádatel'sky orientovaného vyučovania

Otvorená otázka poskytla učitel'om možnost' vyjadrit', čo by mohlo zvýšit' ich úroveň bádatel'sky orientovaného vyučovania. Presná polovica 20 učitel’ov tvrdí, že práve školenie a jeho rôzne alternatívy (seminár, online seminár, prednášky, kurzy, d’alšie vzdelávanie $\mathrm{v}$ tejto problematike, širšia 
databáza námetov na BOV, workshopy, webináre, účast' na otvorenej hodine, názorné ukážky a príklady, iné stretnutia $\mathrm{v}$ metodických centrách) môže prispiet' k zvýšeniu úrovne bádatel'sky orientovaného vyučovania.

Zaznamenane odpovede „neviem“ boli v počte 7 (17,5\%). V kategórii „Iné“ (5 učitel'ov - 12,5\%) zahŕnali návrhy: ,zníženie počtu vyučovacich hodín učitel'om chémie a biológie“, „d’alším kolegom na vyučovani“, „zvýšením platu“, „využivaním viac nápadov a tvorivosti“, ,začat ju reálne využivat““. Lepšie materiálovo - technické vybavenie by uvítali štyria učitelia $(10 \%)$ a najmä vo forme materializácie výučby, vypracovania bádatel'skej metodiky a témy, lepším materiálovo technickým vybavením, technickým vybavením. Dvaja učitelia $(5 \%)$ by uvítali vyššiu časovú dotáciu predmetu a rovnako osvetou (zaujímavým článkom $\mathrm{v}$ učitel'ských novinách, informovat' učitel'ov a robit' osvetu na prilákanie učitel'ov na praktické workshopy, kde by sa vedel učitel' naučit' aplikovat' BOV na svoje predmety).

Učitelia, ktorí odpovedali, že využívajú BOV mohli v d’alšej otvorenej otázke vyjadrit' ako dlho u nich prebiehala transformácia $\mathrm{z}$ klasického vyučovania.

- 6 učitel'ov (15\%) uviedlo, že transformácia neprebiehala, lebo: „BOV je len metóda, použivam ju iba občas“, „nevyuživam túto metódu na každej hodine“, „iba pri niektorých témach/ vždy aktivita závisí od žiakov a ich záujmu“. Učitelia, ktorí uviedli mesiace (2/3/ 5 mesiacov) tvorili 10\% (4 učitelia). Jeden učitel' interpretoval, že ,transformácia prebieha priebežne, nie je ukončená a stále zdokonaluje vyučovanie“. Jeden uviedol, že „transformácia trvala roky“.

Z hl'adiska organizácie vyučovania pri BOV uvádzali respondenti nasledovné odpovede: najčastejšie realizujú $\mathrm{BOV} \mathrm{s}$ jednou triedou $\mathrm{v}$ rámci jedného vyučovacieho predmetu (7 odpovedí, 17,5\%). Využívanie BOV s celým ročníkom (2 odpovede, $5 \%$ ), s viacerými ročníkmi (1 odpoved', 2,5\%), $\mathrm{s}$ jednou triedou $\mathrm{s}$ jedným učitel'om vo viacerých predmetoch (1 odpoved', 2,5\%). Z opýtaných sa nikto nevyjadril za možnost', že na celej škole je zavedené bádatel'sky orientované vyučovanie.

Čo sa týka zhodnotenia prínosu BOV učitel'mi, odpovede korelujú s niektorými predchádzajúcimi zisteniami a to, že rovnaký počet respondentov, ktorí nevyužívajú BOV tiež uvádzali, že nevedia posúdit’ tento spôsob vyučovania (obr. 3 a obr. 4). V hodnoteniach sa však objavili aj negatívne postoje k BOV, čo bližšie ilustruje obr. 4. 


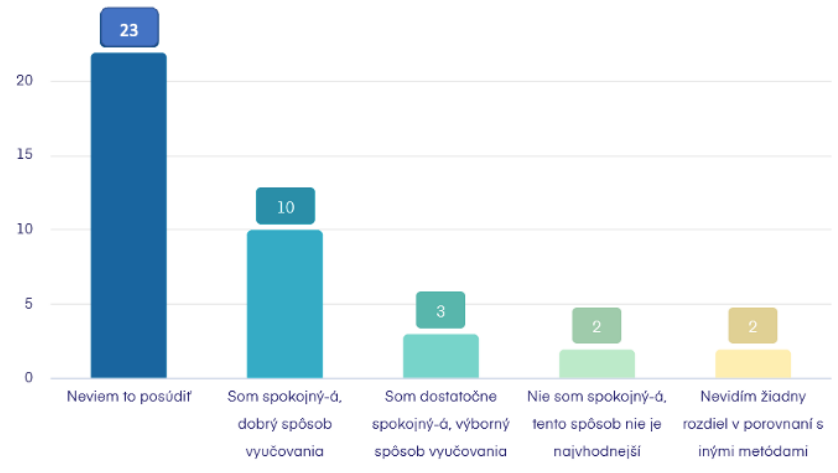

\section{Obr. 4 Zhodnotenie prínosu BOV učitel'mi}

Konkrétne výhody a nedostatky BOV z pohl'adu učitel'ov vyjadrili v rámci formulovania vlastných dôvodov respondenti nasledovne:

\section{Najčastejšie dôvody využívania BOV:}

- žiaci boli viac zaangažovaní a zapojení do vyučovania, aj ked'boli introverti; vyššia aktivita žiakov na vyučovanil aktívne zapojenie žiakov/ aktivizácia žiakov; automotivácia žiakov/ lepšia motivácia; rozvíjanie schopností žiakov/ rozvoj logického a praktického myslenia žiakov dôležitého pre život; deti na to prídu samél objav očami žiakov; socializácia; skupinová práca žiakov/ tímová práca; samostatnost' žiakov a rozvoj zručností; trvalost' vedomostill lepšia fixácia ziskaných vedomostil lepšie utvrdenie poznatkov; žiaci vidia, že vedomosti, ktoré sa naučia majú praktické využitie v bežnom živote; možnost' využit' pobyt v prírode; vyskúšanie si organizačných zručností pri práci.

\section{Dôvody nevyužívania bádatel'sky orientovaného vyučovania:}

- náročnost' hodnotenia (individuálne hodnotenie žiakov je obtiažnejšie/náročnejšie); čas na prípravu/ časová náročnostłčasová strata (nedostatok času na vyriešenie problému úlohy); náročnost' organizáciel náročné na vlastnú realizáciu; nezáujem žiakov; slabé výsledky v porovnaní s využitím iných metód; dlhši čas na dosiahnutie výsledkov (vhodné pre blokové vyučovanie); chýba medzi predmetové prepojenie učiva; nie každý má možnost' využivat' to.

\section{Diskusia}

Lukač et al. (2016) odporúčajú z dôvodu komplexného rozvoja bádatel'ských zručností žiaka a $\mathrm{z}$ dôvodu špecifík jednotlivých predmetov, aby sa $\mathrm{s}$ bádatel'sky orientovaným vyučovaním žiak stretol v čo najpestrejšej množine predmetov. Kl'účovým faktorom úspešnej implementácie bádatel'sky orientovaného vyučovania je učitel', ktorý by okrem pozitívneho postoja $\mathrm{k}$ BOV mal byt' sám bádatel'om. Bádatel'om vo svojom odbore a bádatel'om vo vyučovaní svojho odboru. Ganajova (2012) formuluje závery, aby učitelia naraz používali BOV vo viacerých predmetoch na jednej škole na získanie pozitívnych výsledkov aj z dlhodobého hl'adiska. 
Podl'a Dostala (2015) učitelia potrebujú mat' na realizáciu bádatel'sky orientovanej výučby osvojený súbor kompetencií a byt' presvedčení o prínose BOV. V našom prieskume sa taktiež potvrdilo, že počet učitel'ov, ktorí BOV uplatňujú, tak k nej aj majú pozitívnejšie postoje v porovnaní s ostatnými učitel'mi. Význam vzdelávania a prípravy učitel'ov potvrdzujú mnohí súčasní autori ako napr. Cuenca (2021), Blanchard et al. (2008), Cipkova \& Karolcik (2018) a d'alší.

Odpovede viacerých učitel'ov poukazujú na pozitívne hodnotenia BOV, ak ho využívajú a vyjadrenia $\mathrm{k}$ pozitívnej stránke vyučovania, napríklad zvýšená aktivita u žiakov a socializácia, sú potvrdené aj rôznymi autormi. Slepakova a Kimakova (2015) považujú BOV za jednu z možností, ako zvýšit' zapojenost' žiaka do vyučovania a jeho aktívny prístup k vzdelávaniu. Leškova, Skupekova a Kimakova (2019) v bádatel'sky orientovanej výučbe zaznamenali zvýšenú mieru sociálnej interakcie medzi žiakmi hlavne prostredníctvom zdiel'ania ich myšlienok a nápadov. Posilnila sa ich motivácia a tímová práca, čo ma nesmierny vplyv na budovanie pozitívneho vzt’ahu k zvolenému študijnému odboru. Zlepšenie zručností potrebných na realizáciu činnosti, pretože žiaci si uvedomujú ich význam. Lepšie dokážu prezentovat' výsledky vlastnej činnosti.

Výsledky z domácich a zahraničných výskumov, ktoré sa zaoberajú problematikou BOV (Minner, Levy \& Century, 2009; Brickman et al., 2009; Doubrava, 2014; Kireš et al., 2016; Sotakova, 2018) poukazujú na kladné stránky bádatel'sky orientovanej výučby a potvrdzujú a dopĺnajú skúsenosti učitel'ov v našom dotazníkovom prieskume, že: zvyšuje porozumenie poznatkov a pojmov, zvyšuje trvácnost' vedomostí, rozvíja zručnosti 21. storočia, a to vedecké a kognitívne, je vhodná pre prospechovo slabších aj lepších žiakov (vrátane nadaných žiakov), vhodná pre všetky stupne vzdelávania žiakov, dá sa realizovat' na rôznych úrovniach - od kladenia problémových otázok až po otvorené vyučovanie, rozvíja spôsobilosti vedeckej práce ako sú tvorba hypotéz, plánovanie, experimentovanie, argumentácia, tvorba záverov, podporuje zodpovednost' žiakov za vlastné učenie sa, umožňuje formovat' postoje a názory žiakov na význam prírodovedného vzdelávania a vedy pre život, nie je viazané na prostredie, v ktorom prebieha - môže to byt' bežná školská trieda, školské laboratórium alebo elektronické vzdelávacie prostredie (napríklad počítačom podporované experimenty, virtuálne alebo vzdialené laboratórium).

Aplikácia bádatel'sky orientovanej výučby na Slovensku a v Českej republike poukázala na problémové stránky (Brtnova Čepičkova, 2013; Dostal, 2015; Kireš et al.,2016; Sotakova, 2018), niektoré z problematických stránok rovnako odrádzajú aj učitel'ov nášho prieskumu a to: vel'ký počet žiakov v triede, nízka časová dotácia vyučovacích hodín na aplikovanie bádania, obmedzenia súvisiace s dodržiavaním učebných plánov, nedostatočné vstupné vedomosti a zručnosti žiakov na bádanie, časová náročnost' na prípravu a realizáciu bádatel'sky orientovanej výučby, nedostatok či nedostupnost' výučbových materiálov, nedostatočná technickomateriálna vybavenost' škôl, otázka hodnotenia $\mathrm{v}$ bádatel'sky orientovanej výučbe (čo a ako hodnotit'), nepripravenost' učitel'ov a budúcich učitel'ov na aplikáciu bádatel'sky orientovanej výučby.

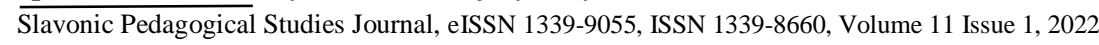


Napríklad chýbajúce materiálovo-technické zabezpečenie uvádzané respondentmi potvrdzujú aj Karolčik a Čipkova (2015) vo výskumoch, že pri zavádzaní inovatívnych učebných metód a postupov, učitelia najviac oceňujú pomoc $\mathrm{v}$ podobe kvalitných metodických materiálov a didakticky dôkladne prepracovaných modelov vyučovacích hodín. Rovnako aj Kireš et al. (2016) publikujú z výskumov, že je potrebné dotváranie a rozširovanie metodických materiálov pre učitel'a, pracovných listov pre žiaka a d'alších podporných materiálov pre BOV, zároveň vzdelávanie učitel’ov a získavanie skúseností z bádatel'skej výučby. Slepakova a Kimakova (2015) publikujú z výskumu s učitel'mi o chýbajúcich vhodných nástrojoch, ktoré by učitel'om v tomto procese pomohli.

Stredoškolskí učitelia vyjadrili $\mathrm{v}$ dotazníku okrem iných prekážok aj náročnost' hodnotenia žiaka ako jedno z negatív v bádatel'sky orientovanom vyučovaní. Žiaci realizujú samostatne viac krokov bádatel'ského cyklu, učitel' sa musí pred realizáciou konkrétnej bádatel'skej aktivity rozhodnút', na ktorú zručnost' bude orientovat' hodnotenie a preto je možno z pohl'adu hodnotenia výsledkov žiakov učitel'mi realizácia BOV v praxi menej častá a logicky aj náročnejšia.

\section{Záver}

V rámci spracovania štúdie sme zistili, že informovanost' učitel'ov o BOV dosahuje $55 \%$, ale praktická pravidelná implementácia je relatívne nízka. Názory a skúsenosti stredoškolských učitel'ov spojené s uplatňovaním bádatel'sky orientovaného vyučovania sa rôznia $\mathrm{v}$ závislosti od ich poznatkov o BOV. Z výsledkov vyplynulo, že nie všetci učitelia sú ochotní venovat' svoj čas d’alšiemu vzdelávaniu. Napriek tomu, že niektorí učitelia využívajú bádatel'sky orientované vyučovanie alebo uvádzajú že ho poznajú, prevažovali charakteristiky BOV len so synonymickým prekladom pojmu bez podrobného vysvetlenia. Celková informovanost' učitel'ov o BOV sa pohybovala nad polovicou a obdobne polovica učitel'ov vie aj intuitívne vysvetlit', čo zahrňuje dané vyučovanie. Praktická implementácia BOV v edukačnej praxi však má svoje rezervy, učitelia si uvedomujú pozitívne ale aj problematické stránky jeho uplatňovania. Jedným z hlavných dôvodov, ktorý odrádza učitel'ov vyučovat' BOV je časová náročnost' na prípravu a realizáciu a nedostatok informácií a práve vzdelávacie aktivity a školenia a odborná literatúra sa ukazujú vhodným prostriedkom na riešenie do budúcnosti.

$\mathrm{Na}$ základe dotazníkového prieskumu sumarizujeme profil stredoškolského učitel'a, ktorý využíva bádatel'sky orientované vyučovanie najčastejšie. Na základe našich výsledkov, je najväššie zastúpenie žien, ich veková štruktúra je v priemere medzi 41-50 rokom veku a s pedagogickou praxou nad 16 rokov, s absolvovaným vysokoškolským vzdelaním učitel'ského zamerania a predmetovou kombináciou biológia a chémia. Ďalšieho vzdelávania v oblasti BOV sa zúčastnila väčšina učitel'ov, ktorí BOV aj využívajú v praxi, na základe čoho konštatujeme, že absolvovanie akéhokol'vek vzdelávania je predpokladom aj aktívnej implementácie poznatkov. Organizačná štruktúra preferovaná u učiteliek využívajúcich BOV je $\mathrm{v}$ jednej triede a $\mathrm{v}$ rámci jedného predmetu (17,5\%). Učitel'ky 
uplatňujúce BOV väčšinou konštatujú, že u nich prebehla transformácia na bádatel'sky orientované vyučovanie v priebehu mesiacov.

Uvedomujeme si limity nášho prieskumu najmä v rozsahu a štruktúre nami skúmanej vzorky učitel'ov a subjektívnymi výpoved'ami respondentov na problematiku, ktoré mohli byt' čiastočne skreslené, preto považujeme tento text za východisko realizácie podrobnejších skúmaní na vybrané oblasti realizácie BOV v praxi.

Dôležité pre zvýšenie informovanosti a zručností učitel'ov pre aplikovanie prvkov BOV vedukačnom procese je jeho dôkladnejšia implementácia do obsahu učitel'skej prípravy. Avšak významnejšou oblast'ou je zrejme d'alšie vzdelávanie v profesijnom rozvoji učitel'ov, ktoré dokáže flexibilnejšie reagovat' na inovácie a trendy v edukácii, projekty na vzdelávanie na medzinárodnej úrovni, organizovanie školení, inovačné metodické materiály a napríklad aj modernizácia materiálno-technického vybavenia v školách.

\section{Bibliographic references}

Blanchard, M. R., Southerland, S.A. \& Grangerova, E. M. (2008). No silver bullet for inquiry: making sense of teacher change following an inquiry-based research experience for teachers. Science Teacher Education, 93 (2), pp. 32263 360. https://doi.org/10.1002/sce.20298

Brickaman, P., Gormally, C., Amstrong, N. \& Hallar, B. (2009). Effects of Inquiry-based Learning on Students' Science Literacy Skills and Confidence. International Journal for the Scholarship of Teaching and Learning, 3 (2), pp. 1-24. ISSN 1931-4744

Brtnova Cepickova, I. (2013). Didaktika prirodovedneho zakladu. Usti nad Labem : Univerzita J. E. Purkyně. ISBN 978-80-7414-597-1

Cipkova, E. \& Karolcik, S. (2018). Assessing of scientific inquiry skills achieved by future biology teachers. Chemistry-Didactics-EcologyMetrology. 23 (1- 2), pp. 71-80. https://doi.org/10.1515/cdem-2018- 0004

Clapps, D. K., Crawford, B. A. (2012). Inquiry-based Instruction and teaching about nature of science: Are they happening? Journal of Science Teacher Education, 24 (3), pp. 497-526. ISSN-1046-560X

Crawford, B. A. (2000). Embaracing the essence of inquiry: new roles for science teachers. Journal of research in Science education, 37 (9), pp. 916937. ISSN-0022-4308

Cuenca A. (2021). Proposing Core Practices for Social Studies Teacher Education: A Qualitative Content Analysis of Inquiry-Based Lessons. Journal of Teacher Education. 72 (3), pp. 298-313. doi:10.1177/0022487120948046

Dostal, J. (2015). Badatelsky orientovana vyuka: pojeti, podstata, vyznam a prinosy. Olomouc : Univerzita Palackeho v Olomouci. ISBN 978-80-2444393-5

Doubrava, L. (2014). Badatelske dovednosti jsou povinnou soucasti kurikula. Ucitelske noviny, 117 (26), pp. 4-6. ISSN 0139-5718

Ganajova, M. (2012). Badatelska metoda vo vyucbe chemie. Kosice : UPJŠ. Available online:

http://www.statpedu.sk/files/articles/dokumenty/vzdelavacieaktivity/04_ibse_chemia.pdf. 
Ganajova, M. \& Sotakova, I. (2018). Ako naplnat poziadavky pre vyucbu chemie v 21. storoci. Chemicke listy, 112 (1), pp. 43-51. ISSN 0009-2770

Jeskova, Z., Kires, M. \& Onderova, L. (2012). Skolska reforma na Slovensku meni sposob vyucby prirodnych vied. Ceskoslovensky casopis pre fyziku, 62 (5-6), pp. 316-321. ISSN 0009-0700. https://docplayer.cz/145025034-5-62012-ceskoslovensky-casopis.html

Karolcik, S. \& Cipkova, E. (2015). Vyuzitie badatelsky orientovanych metod vo vyucovani geografie. Geograficka revue, 11 (1), pp. 15-47.

Karolcik, S., Lastikova, B. \& Cipkova, E. (2020). Uplatnovanie badania a badatelskych ucebnych metod v geografickom vzdelavani. Casopis Biologie Chemie-Zemepis, $29 \quad$ (4), pp. 25-42. https://doi.org/ 10.14712/25337556.2020.4.3

Kires, M., Jeskova, Z., Ganajova, M. \& Kimakova, K. (2016). Badatelske aktivity v prirodovednom vzdelavani cast A. Bratislava : Statny pedagogicky ustav. ISBN 978-80-8118-155-9. Available online: https://www.statpedu.sk/files/articles/nove_dokumenty/ucebnicemetodikypublikacie/badatelske-aktivity/01cast_a_web.pdf

Leskova, A., Skupekova, M. \& Kimakova, K. (2019). Hodnotenie rozvoja vybranych badatelskych zrucnosti $\mathrm{v}$ sekundarnom vzdelavani ziakov s mentalnym postihnutim. Pedagogicke rozhlady, 28 (2), pp. 21-24. ISSN 1335-0404

Lukac, S., Snajder, L., Gunis, J. \& Jeskova, Z. (2016). Badatelsky orientovane vyucovanie matematiky a informatiky na strednych skolach.

Košice : Univerzita Pavla Jozefa Safarika. ISBN 978-80-8152-471-4

Minner, D., Levy, A. J. \& Century, J. (2009). Inquiry-Based Science Instruction - What Is It Does It Matter? Results from a Reasearch Synthesis Years 1984 to 2002. Journal of Research in Science Teaching, 47 (4), pp. 474-496

Slepakova, I. \& Kimakova, K. (2015). Hodnotenie zrucnosti v badatelsky orientovanej vyucbe biologie. Scientia in educatione, 6 (1), pp. 133-143. ISSN 1804- 7106.

Sotakova, I. (2018). Ucinnost badatelsky orientovanej vyucby $\mathrm{v}$ teme Chemicky dej na zakladnych skolach a gymnaziach : dizertacna praca. Praha : Univerzita Karlova. 115 p.

Spodniakova Pfefferova M., Holec, S., Hruska, M. \& Raganova, J. (2015). Strategia rozvijania badatelsky orientovaneho prirodovedneho vzdelavania $\mathrm{V}$ projekte chain reaction: vyskumna praca. Banská Bystrica : UMB. 215 p.

PaedDr. Tímea Šeben Zat'ková, PhD.

Ing. Zuzana Bobák

Department of Education

University of St. Cyril and Methodius in Trnava

Nám. J. Herdu 2, 91701 Trnava

Slovakia

timea.seben.zatkova@ucm.sk

bobakzuzana@gmail.com 